\title{
Sciendo
}

DOI: 10.2478/orga-2019-0018

\section{Application of the Project Management Methodology Formation's Method}

\author{
Igor KONONENKO and Svitlana LUTSENKO
}

National Technical University "Kharkiv Polytechnic Institute", Strategic Management Department, 61002 Kharkiv, Ukraine, igorvkononenko@gmail.com, lutsenkosyu@gmail.com.

\begin{abstract}
Background and Purpose: The selection of a "right" project management methodology for a particular project represents a problem of great importance. Its solution affects crucial project parameters like cost, duration, product quality, and the project's success in general. The purpose of this study is to present a method for the formation of the project management methodology and illustrate its applicability on a software development project's example.

Design/Methodology/Approach: In this study, we describe the method of project management methodology formation that allows the forming of a specialized methodology for any IT project considering the fuzziness of information about the project, its environment, and existing expert's recommendations. The method involves 1) collecting baseline information using a questionnaire, 2) calculating weighted Hamming and Euclidean distances, 3) solving a three-criterion optimization problem using a minimax approach with fuzzy input data.

Results: All six stages of the project management methodology formation's method (project evaluation, basis selection, alternative methodologies formation, methodology selection, methodology application, and methodology tailoring) were applied to form a specialized project management methodology for an IT project to increase the possibility of its success. The most appropriate alternative based on DSDM was selected and applied to manage the project. Conclusions: The given method allows the forming of a specialized project management methodology based on the components of Generalized Body of Knowledge for any IT project considering specific conditions of the project and its environment.
\end{abstract}

Keywords: Methodology, Project management, Formation, Application, Method.

\section{Introduction}

With the growth of competition in the global market and rapid changes in applied technologies, project management is becoming one of the most sought-after areas of management. Dozens of project management guides, standards, and methodologies have been created. Their main strengths are 1) the systematic character, 2) the use of computer science achievements, 3) the application of process-oriented approaches, 3 ) the use of various information collecting and processing methods, and 4) the use of decision-making support methods. Due to the large number of existing developments in this area, the choice of a management methodology for a specific project, represents a complex task. Its solution affects crucial project parameters like cost, duration, product quality, and the project's success in general. The chosen methodology impacts the agility of an enterprise, as well as its further development possibilities (Kryvinska, 2012).

The purpose of the study is to propose a method for the project management methodology formation and illustrate its applicability on a software development project's example.

The study has the following structure:

1. Introduction. The section describes the motivation of the study, its aim, and its structure.

2. Literature Review. The section provides a review and analysis of the latest publications dedicated to project management methodology selection and formation.

3. The Project Management Methodology Formation's

Received: June 14, 2019; revised: October 18, 2019; accepted: November 12, 2019 
Method. The section contains information about Project Management Methodology Formation's Method: its information support, main stages, and their descriptions.

4. Application of the Project Management Methodology Formation's Method to a Software Development Project. The section illustrates an example of a practical application of the method described in Section 3 to a software development project.

\section{Literature Review}

While project performance has been increasing globally (in 2018 , nearly $70 \%$ of projects met their original goals and nearly $60 \%$ were completed within the original budget compared to $62 \%$ and $50 \%$ respectively in 2016 according to $\mathrm{PMI}$ ), the project failure rate is still high.

According to an Harvard Business Review survey, the average IT project overran its budget by $27 \%$ and at least one in six IT projects turns into a "black swan" with a cost overrun of $200 \%$ and a schedule overrun of $70 \%$ (Harvard Business Review, 2011).

A PricewaterhouseCoopers (PwC) studied 10,640 projects and found that only $2.5 \%$ of companies complete their projects $100 \%$ successfully. The rest projects either failed to meet some of the aims or missed the original budget or deadlines (Gallup, 2012).

According to PwC (PricewaterhouseCoopers, 2012), the usage of project management methodologies improves project performance. So organizations that use a methodology comparing to organizations that don't, more often meet budget $(38 \%$ vs. $31 \%)$, stay on schedule ( $28 \%$ vs. $21 \%)$, meet scope $(71 \%$ vs. $61 \%)$, meet quality standards (68\% vs. $60 \%)$, meet expected benefits $(60 \%$ vs. $51 \%)$.

An author of (Whitaker, 2014) showed the results of a survey of 202 project management specialists from 15 sectors of the economy. Among the respondents, $42 \%$ were organizations that do not have a project management methodology. These respondents noted that their projects were successful in $67 \%$ of cases. Respondents who use mostly tailored project management methodology $(37 \%$ of respondents) reported that projects succeed in $73 \%$ of cases. Those who use a fully tailored project management methodology ( $7 \%$ of respondents) indicated that projects were successful in $82 \%$ of cases. Among those who do not have a project management methodology, 29\% do not know how to build a methodology.

The task of the project management methodology selection is the subject of various studies. For example, the study (Bushuev \& Neizvestnyy, 2013) present a genome model for the project, program, and portfolio management methodologies. It gives a formal description of the genome as a system of knowledge about these methodologies and defines the methodology in the genome using an object-oriented approach. The methodologies database structure allows the storing of all project management methodologies in a single system and format.

The results of a study (Joslin \& Müller, 2015) indicate the importance of having a comprehensive project management methodology and the experience of its tailoring as factors of project success.

The authors (Joslin \& Müller, 2016) have shown that there is a connection between the elements of a project management methodology and the characteristics by which the project's success is evaluated. The methodology's elements have the highest impact on the time, cost and scope of the project.

The study (Čelesnik, Radujković, \& Vrečko, 2018) demonstrates the impact of the applied project management methodology on solving company problems in a crisis. In (Rehman \& Hussain, 2007), five project management methodologies: Agile Development Methods, MSF, PRINCE2, RUP, ITIL were compared with PMBOK Guide (PMI, 2004). As a result of the comparison, the authors noted that the main criteria for choosing the methodology should include the following: work experience, experts' opinions, state regulation, stakeholders' and client's preferences, and the client location.

The authors of (Boehm \& Turner, 2004) have suggested a risk-based approach to balance Agile and Plan-driven methodologies. They identified five dimensions, which from their perspective are crucial in describing an organization or a project in Agile and Plan-driven characteristics. Among these dimensions are size, criticality, dynamism, personnel, and culture. The graphical representation of an organization or a project promotes the definition of its environment and, following, the application of the risk-based approach described in the paper for a balanced development strategy construction.

The results of (Conforto, et al., 2014) indicate that besides software development, Agile Project Management can be adopted by other industries, but there should be some enablers for its implementation. These enablers relate to the experience of project teams and project managers, project teams size and location, the involvement of customer/stakeholders in the project planning, etc.

In (PMI, 2017b), the Model for Suitability of Agile Approach is proposed. This model demands the survey of a project team on nine issues concerning the cultural context of the project, the project team, and the project itself. Depending on the answers, the model recommends the usage of Agile, predictive or hybrid approach.

The authors (Kononenko \& Lutsenko, 2018) proposed the method of a specialized methodology formation for a specific project. The method considers the unique characteristics of every project, its parameters, and parameters of its environment. However, the authors have not illustrated how the given method could be put into practice.

The aim of the study is to demonstrate how the method of project management methodology formation (Kononenko \& Lutsenko, 2018) could be applied to a project to form the most appropriate management methodology for 
its conditions. We will illustrate and evaluate the applicability of the method on a small-size software development project's example.

\section{The Project Management Methodology Formation's Method}

There are various project management standards, guides, and methodologies. But for now, there is no unity in the scientific world about a 'project management methodology' definition. In this regard, we have analyzed existing versions of its definition and have considered the following (Kononenko, Aghaee, \& Lutsenko, 2016): the project management methodology is a certain and documented system of principles, rules, processes, practices, life cycle, organizational structure, prescribed roles that provide the project management.
To form such methodology for specific conditions of a particular project, we will apply the project management methodology formation's method (Kononenko \& Lutsenko, 2018b). The method can also be applied to a group of projects or to all projects of an organization under specific conditions which will be described later in the section. The method implies the usage of Generalized Body of Knowledge on Project Management (GBOK), which contains information from the commonly known project management standards, methodologies, and guides (Kononenko \& Lutsenko, 2018a). Particularly, it includes information from PMBOK guide (PMI, 2018a), ISO21500 standard (ISO, 2012), PRINCE2 method (OGC, 2017), SWEBOK guide (IEEE, 2014), Scrum (SCRUMstudy, 2016), Kanban (Anderson, 2010), XP (Beck, 2004), DSDM (Agile Business Consortium, 2014), and FDD (Gorakavi, 2009) agile methodologies, as well as information gathered from the specialists' propositions. Figure 1 illustrates the structure of $\mathrm{GBOK}$.

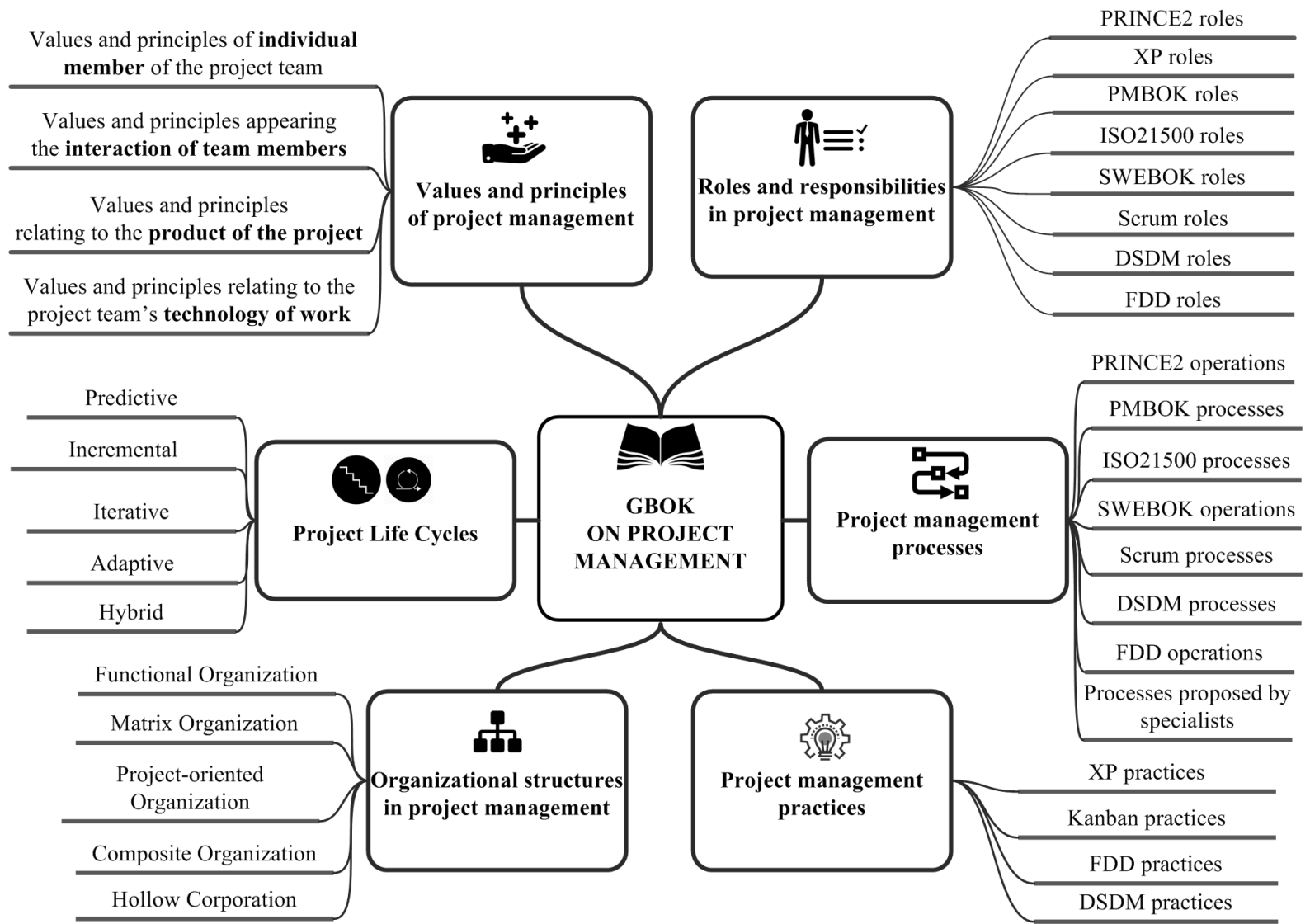

Figure 1: The GBoK structure (Kononenko \& Lutsenko, 2018b) 
The application of the project management methodology formation's method implies the fulfillment of the following stages.

\section{1) Evaluate the project}

Fill in the questionnaire about the project and its environment. The questionnaire is described in (Kononenko \& Lutsenko, 2018b). It includes questions about the size of the project team, its competence, customer's experience of working with this team, project manager's responsibilities, the main requirements to the project, and the risk events occurrence probability. It is advisable to involve project stakeholders in filling the questionnaire.

\section{2) Select the basis}

Select a primary approach to project management using the method given in (Kononenko \& Lutsenko, 2017). The method allows selecting the most suitable approach from the generally known standards, guides, and methodologies (PMBOK, PRINCE2, SWEBOK, Scrum, XP, and Kanban). Use the selected approach as a basis for further specialized methodology formation.

\section{3) Form alternative methodologies}

Set several specialized methodology alternatives. Modify the primary approach or create your basis using principles, rules, processes, practices, life cycles, and organizational structures represented in GBOK. Distribute roles and responsibilities in the project and define connections between processes and other components. Delete or modify components if appropriate. It is advisable to involve an expert to form alternatives properly.

\section{4) Select methodology}

Select the most appropriate methodology from alternatives created on the previous stage. For the selection, use the method of three-criterion optimization described in (Kononenko, Aghaee \& Lutsenko, 2016). The method allows selecting the best methodology by the management activities laboriousness and cost, as well as the risks associated with the implementation of the methodology.

\section{5) Apply methodology}

Apply the selected specialized methodology to the project management.

\section{6) Tailor methodology}

During the project implementation, tailor the project management methodology components and links between them periodically. For the tailoring, use the following criteria: the management activities laboriousness, the management activities cost, and the risks associated with the methodology implementation.

The complex collection of relevant project data in the pre-initialization phase could be time and cost consum- ing. But these expenses are justified for large, complex, expensive, and responsible projects. According to the statistics, large projects (more than $\$ 10$ million) have a higher failure rate $(38 \%)$ than small projects $(4 \%)$ (The Standish Group, 2013). The dependency between the project size and failure rate is also mentioned in Gartner's research (Gartner, 2012): “An IT project with a budget over \$1M is $50 \%$ more likely to fail than one with a budget below $\$ 350,000$. For such large IT projects, functionality issues and schedule overruns are the top two causes of failure (at $22 \%$ and $28 \%$ respectively)". That is why the application of the method to a large project to increase the probability of its success is reasonable.

The method also can be applied to a group of projects or all projects of an organization. In this case, the diversity of all projects of the organization should be considered (IT projects, marketing projects, production projects, etc.). It is advisable to define groups of projects that are to be managed with one methodology. Such groups could be defined on Stage 2 of the method: if the basic methodologies for several projects are the same, the projects can be united into a group.

The method can be applied to any projects, but it should be taken into account that some of the approaches included in GBOK apply only to IT projects (SWEBOK, XP, FDD)

\section{Application of the Project Management Methodology Formation's Method to a Software Development Project}

Let us illustrate the proposed method application. As an example, we will consider a software development project. The project product is a web application for the synthesis of the project management guide PMGuide. The expected duration of the project is 1.5 months. Project management cost should not exceed $\$ 1,750$.

\subsection{Project evaluation}

On the first stage of the method, stakeholders evaluate the project by filling a special questionnaire (Kononenko \& Lutsenko, 2017).

Each question of the questionnaire represents a project

parameter $X_{k}, k=\overline{1, K}$ (e.g. 'Number of people involved in the project' is the first parameter of a project evaluation - $\mathrm{x}_{1}$, 'Customer's experience of working with this project team' is the second parameter $-\mathrm{x}_{2}$ etc.). The total number of parameters is $\mathrm{K}=23$.

Every parameter has four values $X_{k}=\left\{x_{1 k}, x_{2 k}, \ldots, x_{4 k}\right\}$ that correspond with possible situations in a project. For 
example, the project parameter 'Number of people involved in the project' can be: 'More than 100 people' $\left(\mathrm{x}_{11}\right.$ $=1)$, 'From 30 to 100 people' $\left(x_{21}=2\right)$, 'From 10 to 30 ' $\left(x_{31}\right.$ $=3$ ), and 'Less than 10 people' $\left(\mathrm{x}_{41}=4\right)$.

Stakeholders evaluate the project using given parameters by mapping the project to parameters values using a membership function (Kononenko \& Lutsenko, 2017). The project evaluation $B=\left\{B_{1}, B_{2}, \ldots, B_{K}\right\}$ represents a fuzzy set where $\quad B_{k}=\left\{\left\langle x_{1 k}, \mu_{B_{k}}\left(x_{1 k}\right)\right\rangle,\left\langle x_{2 k}, \mu_{B_{k}}\left(x_{2 k}\right)\right\rangle, \ldots,\left\langle x_{k}, \mu_{B_{k}}\left(x_{k}\right)\right\rangle\right\}$. Membership function $\mu_{B_{k}}\left(x_{k}\right), i=\overline{1, I}$ defines how the project is mapped to the $\mathrm{i}$-th situation of the $\mathrm{k}$-th questionnaire parameter.

If one of the parameter's possible situations entirely meets the project and three others are not suitable, the value of membership function for the suitable situation equals
1 and for three others it equals 0 . For example, the evaluation $B_{2}=\{\langle 1,0\rangle,\langle 2,0\rangle,\langle 3,1\rangle,\langle 4,0\rangle\}$ means that the project customer has never worked with any member of the project team but a team leader.

If one possible situation cannot fully describe the project conditions, the membership function value will show the compliance degree between the project and all parameter's possible situations. For example, the evaluation $B_{3}=\{\langle 1,0\rangle,\langle 2,0.5\rangle,\langle 3,0.5\rangle,\langle 4,0\rangle\}$ demonstrates the case when the project's conditions cannot be described by one possible situation of the parameter 'Work experience in the given field'. This evaluation shows that half of the project team has less than 2 years of work experience while the other half has been working in the given field from 2 to 5 years.

The PMGuide development project evaluation gained from its main stakeholders is shown in Table 1.

Table 1: Project evaluation (B)

\begin{tabular}{|c|c|c|c|}
\hline Parameter, $X_{k}$ & Possible situation, $i=1,4$ & $\begin{array}{l}\text { Parameter } \\
\text { value, } x_{i k}\end{array}$ & $\begin{array}{l}\text { Membership } \\
\text { function, } \\
\mu_{B_{k}}\left(x_{k}\right)\end{array}$ \\
\hline \multicolumn{4}{|c|}{ Number of people involved in the project } \\
\hline \multirow{4}{*}{$\begin{array}{l}\text { Number of people involved in } \\
\text { the project, } X_{1}\end{array}$} & More than 100 & 1 & 0 \\
\hline & From 30 to 100 & 2 & 0 \\
\hline & From 10 to 30 & 3 & 0 \\
\hline & Less than 10 & 4 & 1 \\
\hline \multicolumn{4}{|c|}{ Customer's experience of working with this project team } \\
\hline \multirow{4}{*}{$\begin{array}{l}\text { Customer's experience of } \\
\text { working with this project team, } \\
\mathrm{X}_{2}\end{array}$} & Has never worked with this team & 1 & 0 \\
\hline & Worked with some members of the team & 2 & 0 \\
\hline & Worked with the project team leader & 3 & 1 \\
\hline & $\begin{array}{l}\text { One or more common projects with the whole } \\
\text { project team }\end{array}$ & 4 & 0 \\
\hline \multicolumn{4}{|c|}{ Evaluation of the Project Team's Competence by the Project Manager } \\
\hline \multirow{4}{*}{$\begin{array}{l}\text { Work experience in the given } \\
\text { field, } \mathrm{X}_{3}\end{array}$} & No work experience & 1 & 0 \\
\hline & Less than 2 years of work experience & 2 & 0.5 \\
\hline & From 2 to 5 years of work experience & 3 & 0.5 \\
\hline & More than 5 years of work experience & 4 & 0 \\
\hline
\end{tabular}




\begin{tabular}{|c|c|c|c|}
\hline Parameter, $X_{k}$ & Possible situation, $i=\overline{1,4}$ & $\begin{array}{l}\text { Parameter } \\
\text { value, } x_{i k}\end{array}$ & $\begin{array}{l}\text { Membership } \\
\text { function, } \\
\mu_{B_{k}}\left(x_{k}\right)\end{array}$ \\
\hline \multirow{4}{*}{$\begin{array}{l}\text { Understanding of } \\
\text { requirements, adapting } \\
\text { ability, initiative, } X_{4}\end{array}$} & $\begin{array}{l}\text { Almost do not understand the requirements; require frequent } \\
\text { explanations and constant control }\end{array}$ & 1 & 0 \\
\hline & $\begin{array}{l}\text { Understand the requirements, can follow them, but require } \\
\text { regular control }\end{array}$ & 2 & 0.5 \\
\hline & $\begin{array}{l}\text { Understand the requirements, can follow them, do not require } \\
\text { regular control }\end{array}$ & 3 & 0.5 \\
\hline & $\begin{array}{l}\text { Have a good understanding of the requirements; can follow } \\
\text { them without regular control; can suggest better alternatives }\end{array}$ & 4 & 0 \\
\hline \multirow{4}{*}{$\begin{array}{l}\text { Cooperation experi- } \\
\text { ence, } \mathrm{X}_{5}\end{array}$} & Have never worked together & 1 & 0.33 \\
\hline & $\begin{array}{l}\text { Worked together on the creation of a product but in the different } \\
\text { field }\end{array}$ & 2 & 0 \\
\hline & $\begin{array}{l}\text { Worked together on the creation of one product in a field of } \\
\text { interest }\end{array}$ & 3 & 0.67 \\
\hline & $\begin{array}{l}\text { Worked together on the creation of several products in the field } \\
\text { of interest }\end{array}$ & 4 & 0 \\
\hline \multirow{4}{*}{$\begin{array}{l}\text { Knowledge of applied } \\
\text { tools and methods, } X_{6}\end{array}$} & $\begin{array}{l}\text { Tools and methods, applied in the given project, have never } \\
\text { been used before and are unknown to the team }\end{array}$ & 1 & 0 \\
\hline & $\begin{array}{l}\text { Tools and methods, applied in the project, are known to the team } \\
\text { but have never been used before }\end{array}$ & 2 & 0 \\
\hline & $\begin{array}{l}\text { Tools and methods, used in the project, are known to the team } \\
\text { but are rarely used }\end{array}$ & 3 & 0 \\
\hline & $\begin{array}{l}\text { Tools and methods are known to the team and have been widely } \\
\text { used before }\end{array}$ & 4 & 1 \\
\hline \multirow{4}{*}{ Learning ability, $\mathrm{X}_{7}$} & $\begin{array}{l}\text { It is hard for the team to learn new knowledge and technologies, } \\
\text { and to adjust to changes }\end{array}$ & 1 & 0 \\
\hline & $\begin{array}{l}\text { For some members of the team, it is hard to learn new informa- } \\
\text { tion and technologies, but the team can adjust to changes }\end{array}$ & 2 & 1 \\
\hline & Easily absorb new knowledge, can adjust to changes & 3 & 0 \\
\hline & $\begin{array}{l}\text { The team can easily absorb information, always tries to learn } \\
\text { something new; can well adjust to the changes }\end{array}$ & 4 & 0 \\
\hline \multirow{4}{*}{$\begin{array}{l}\text { Team's ability to } \\
\text { clearly formulate and } \\
\text { openly express ideas, } \\
\mathrm{X}_{8}\end{array}$} & Can't clearly formulate ideas and rarely express them & 1 & 0 \\
\hline & Can clearly formulate their ideas but rarely express them & 2 & 0.17 \\
\hline & Can clearly formulate their ideas and openly express them & 3 & 0.66 \\
\hline & Can clearly formulate, openly express and justify their ideas & 4 & 0.17 \\
\hline \multirow{4}{*}{$\begin{array}{l}\text { Ability to admit mis- } \\
\text { takes, } \mathrm{X}_{9}\end{array}$} & Don't admit their mistakes and can't learn from them & 1 & 0 \\
\hline & Rarely admit their mistakes but try to never make them again & 2 & 0 \\
\hline & Openly admit their mistakes and try to never make them again & 3 & 1 \\
\hline & Openly admit their mistakes and always learn from them & 4 & 0 \\
\hline
\end{tabular}




\begin{tabular}{|c|c|c|c|}
\hline Parameter, $X_{k}$ & Possible situation, $i=\overline{1,4}$ & $\begin{array}{c}\text { Parameter value, } \\
x_{i k}\end{array}$ & $\begin{array}{l}\text { Membership } \\
\text { function, } \\
\mu_{B_{k}}\left(x_{k}\right)\end{array}$ \\
\hline \multirow{4}{*}{$\begin{array}{l}\text { Ability to admit mis- } \\
\text { takes, } \mathrm{X}_{9}\end{array}$} & Don't admit their mistakes and can't learn from them & 1 & 0 \\
\hline & Rarely admit their mistakes but try to never make them again & 2 & 0 \\
\hline & Openly admit their mistakes and try to never make them again & 3 & 1 \\
\hline & Openly admit their mistakes and always learn from them & 4 & 0 \\
\hline \multirow{4}{*}{$\begin{array}{l}\text { Team's ability to work } \\
\text { effectively in condi- } \\
\text { tions of freedom or } \\
\text { full regulation, } X_{10}\end{array}$} & Work effectively in conditions of full regulation & 1 & 0 \\
\hline & Work effectively mostly in conditions of regulation & 2 & 0 \\
\hline & Work effectively mostly in conditions of freedom & 3 & 1 \\
\hline & Work effectively in conditions of full freedom & 4 & 0 \\
\hline \multicolumn{4}{|c|}{ Reporting } \\
\hline \multirow{4}{*}{$\begin{array}{l}\text { Means of communica- } \\
\text { tion, } X_{11}\end{array}$} & Written reports. Formal documentation & 1 & 0 \\
\hline & Online texting (ICQ, E-mail) & 2 & 0 \\
\hline & Voice communication (telephone connection, Internet-conference) & 3 & 0 \\
\hline & Direct communication (meetings, video conferences) & 4 & 1 \\
\hline \multirow{4}{*}{$\begin{array}{l}\text { The frequency of } \\
\text { reporting to the Cus- } \\
\text { tomer, } X_{12}\end{array}$} & Reports on every activity & 1 & 0 \\
\hline & Reports on completing the blocks of work & 2 & 0 \\
\hline & Reports on the readiness of a project product component & 3 & 1 \\
\hline & Reports about project finish & 4 & 0 \\
\hline \multirow{4}{*}{$\begin{array}{l}\text { Understanding the } \\
\text { scope of works, } X_{13}\end{array}$} & There is a full list of works; further alternation is impossible & 1 & 0 \\
\hline & There is a detailed list of works, further alternation is possible & 2 & 0 \\
\hline & There is an approximate list of project works & 3 & 1 \\
\hline & $\begin{array}{l}\text { The team understands the project goal and several ways for its } \\
\text { achievement }\end{array}$ & 4 & 0 \\
\hline \multicolumn{4}{|c|}{ Project Manager's Responsibility and Main Requirements to the Project } \\
\hline \multirow{4}{*}{$\begin{array}{l}\text { Consequences in case } \\
\text { of unsatisfactory proj- } \\
\text { ect outcome, } X_{14}\end{array}$} & The threat to human life & 1 & 0 \\
\hline & Loss of irreplaceable sum of money & 2 & 0 \\
\hline & Loss of a significant sum of money & 3 & 1 \\
\hline & Loss of insignificant sum of money/ reputational loss & 4 & 0 \\
\hline \multirow{4}{*}{ Project cost, $X_{15}$} & More than 1 million $\$$ & 1 & 0 \\
\hline & From 300 thousand to 1 million $\$$ & 2 & 0 \\
\hline & From 100 to 300 thousand $\$$ & 3 & 0 \\
\hline & Less than 100 thousand $\$$ & 4 & 1 \\
\hline \multirow{4}{*}{$\begin{array}{l}\text { Requirements to the } \\
\text { project quality, } X_{16}\end{array}$} & Highest international requirements & 1 & 0 \\
\hline & International requirements & 2 & 0 \\
\hline & National requirements & 3 & 0 \\
\hline & Local requirements & 4 & 1 \\
\hline \multirow{4}{*}{ Requirements to the } & The period is unlimited & 1 & 0 \\
\hline & Not very urgent & 2 & 1 \\
\hline & Urgent & 3 & 0 \\
\hline & Very urgent & 4 & 0 \\
\hline
\end{tabular}




\begin{tabular}{|c|c|c|c|}
\hline Parameter, $X_{k}$ & Possible situation, $i=1,4$ & $\begin{array}{l}\text { Parameter } \\
\text { value, } x_{i k}\end{array}$ & $\begin{array}{l}\text { Membership } \\
\text { function, } \\
\mu_{B_{k}}\left(x_{k}\right)\end{array}$ \\
\hline \multirow{4}{*}{$\begin{array}{l}\text { Requirements to the } \\
\text { precise compliance } \\
\text { with a deadline, } X_{18}\end{array}$} & The deadline should be strictly met & 1 & 0 \\
\hline & Insignificant deviation from the deadline is allowed & 2 & 1 \\
\hline & Considerable deviation from the deadline is allowed & 3 & 0 \\
\hline & Compliance with the deadline is not strictly required & 4 & 0 \\
\hline \multirow{4}{*}{$\begin{array}{l}\text { Requirements change } \\
\text { percent /month, } X_{19}\end{array}$} & Less than $7 \%$ & 1 & 0 \\
\hline & From 7 to $25 \%$ & 2 & 0 \\
\hline & From 25 to $45 \%$ & 3 & 0.5 \\
\hline & More than $45 \%$ & 4 & 0.5 \\
\hline \multicolumn{4}{|c|}{ Risk Events Probability } \\
\hline \multirow{4}{*}{$\begin{array}{l}\text { The probability of } \\
\text { occurrence of risk } \\
\text { events associated with } \\
\text { the object architecture, } \\
\text { technologies, and pro- } \\
\text { cesses of its creation, } \\
\text { quality indicators, } \mathrm{X}_{20}\end{array}$} & Risk events are not likely to occur $[0,0.1]$ & 1 & 0 \\
\hline & Risk events might occur $(0.1,0.5]$ & 2 & 1 \\
\hline & Risk events are highly likely to occur $(0.5,0.75]$ & 3 & 0 \\
\hline & Risk events will most probably occur $(0.75,1]$ & 4 & 0 \\
\hline \multirow{4}{*}{$\begin{array}{l}\text { The probability of } \\
\text { external risk events } \\
\text { occurrence (disruption } \\
\text { of work by contractors, } \\
\text { unfavorable political/ } \\
\text { economic situation in } \\
\text { the country, market } \\
\text { changes, etc.), } X_{21}\end{array}$} & Risk events are not likely to occur $[0,0.1]$ & 1 & 1 \\
\hline & Risk events might occur $(0.1,0.5]$ & 2 & 0 \\
\hline & Risk events are highly likely to occur $(0.5,0.75]$ & 3 & 0 \\
\hline & Risk events will most probably occur $(0.75,1]$ & 4 & 0 \\
\hline \multirow{4}{*}{$\begin{array}{l}\text { The probability of or- } \\
\text { ganizational risk events } \\
\text { occurrence (disruption } \\
\text { of funding, delivery of } \\
\text { resources, inaccurate } \\
\text { prioritizing, etc.), } X_{22}\end{array}$} & Risk events are not likely to occur $[0,0.1]$ & 1 & 0 \\
\hline & Risk events might occur $(0.1,0.5]$ & 2 & 1 \\
\hline & Risk events are highly likely to occur $(0.5,0.75]$ & 3 & 0 \\
\hline & Risk events will most probably occur $(0.75,1]$ & 4 & 0 \\
\hline \multirow{4}{*}{$\begin{array}{l}\text { The probability of } \\
\text { managerial risk events } \\
\text { occurrence (inefficient } \\
\text { planning, controlling, } \\
\text { communication prob- } \\
\text { lems, etc.), } X_{23}\end{array}$} & Risk events are not likely to occur $[0,0.1]$ & 1 & 0 \\
\hline & Risk events might occur $(0.1,0.5]$ & 2 & 0 \\
\hline & Risk events are highly likely to occur $(0.5,0.75]$ & 3 & 1 \\
\hline & Risk events will most probably occur $(0.75,1]$ & 4 & 0 \\
\hline
\end{tabular}




\subsection{Basis selection}

For an expert, it can be easier to form the methodology using some approach as a basis than create it all by himself. The method stage 'Select the basis' is optional but, at least, it allows defining what type of methodology is more appropriate for the project (whether it should be some heavy-weighted plan-driven methodology or a flexible agile, or a hybrid of such methodologies is more beneficial).

Using the project evaluation gained on the previous stage and the method given in (Kononenko \& Lutsenko, 2017) we can select a project management approach that fits the project the most.

Each approach was previously evaluated by its applicability to the situations described in the questionnaire (Table 1) (Kononenko \& Lutsenko, 2017). The degree of compliance between the approach and a specific situation is fuzzy. That is why we used fuzzy sets for its description.

We will consider the applicability of the r-th approach to each situation of the $\mathrm{k}$-th parameter $X_{k}=\left\{x_{1 k}, x_{2 k}, \ldots, x_{k}\right\} \quad$ as a fuzzy set $A_{k}, k=\overline{1, K}$, $A_{k}=\left\{\left\langle x_{1 k}, \mu_{A_{k k}}\left(x_{1 k}\right)\right\rangle,\left\langle x_{2 k}, \mu_{A_{k}}\left(x_{2 k}\right)\right\rangle, \ldots,\left\langle x_{k}, \mu_{A_{k}}\left(x_{k}\right)\right\rangle\right\}$.

The membership function $\mu_{A_{k}}\left(x_{k}\right), i=\overline{1, I}$ defines how the $\mathrm{r}$-th approach is mapped to the $\mathrm{i}$-th situation of the $\mathrm{k}$-th questionnaire parameter. The membership functions of all considered approaches are defined by experts in (Kononenko \& Lutsenko, 2017). Figure 2 illustrates an example of the SCRUM membership function graphical representation for the first questionnaire parameter.

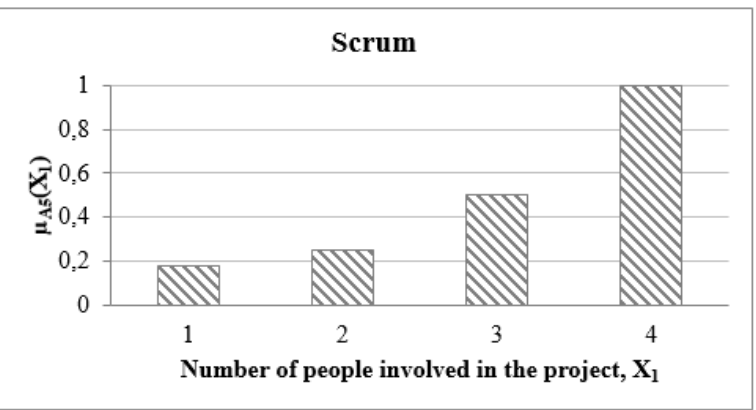

Figure 2: Scrum membership function (parameter $x_{1}$ )

A project management approach $\mathrm{A}_{\mathrm{r}}, r=\overline{1, R}$ is characterized by its applicability to each situation of all parameters (i.e. $A_{r}=\left\{A_{r 1}, A_{r 2}, \ldots, A_{K}\right\}$ ).

The best approach for the project is the closest one. It means that to find the most appropriate approach to managing a project we should calculate fuzzy distances from the project evaluation $B$ to all alternative approaches $A_{r}$, $r=\overline{1, R}$. Calculating total distances, we will take into consideration that the distance between the project evaluation

$\mathrm{B}$ and an approach $\mathrm{A}_{\mathrm{r}}, r=\overline{1, R}$ for the $\mathrm{i}$-th value of the $\mathrm{k}$-th parameter is:

$$
d_{i k}\left(A_{r}, B\right)=\left\{\begin{array}{l}
0, \mathrm{f}\left(\mu_{A_{k k}}\left(x_{i k}\right)-\mu_{B_{k}}\left(x_{i k}\right)\right) \geq 0 \\
\left.\left(\mu_{A_{k}}\left(x_{i k}\right)-\mu_{B_{k}}\left(x_{i k}\right)\right)\right), \text { else. }
\end{array}\right.
$$

In this case, if the value of the membership function for the approach is superior to the value of the membership function for the project or equal to it, the distance between these two coordinates should be considered as zero. In other words, the membership function for the project is covered by the membership function for the approach or, else, the approach is fully consistent with the project.

Formulas for calculation of total Hamming and total Euclidean distances, as well as results of the calculation, are shown in Table 2. The approaches membership functions and project parameters weight coefficients were described in (Kononenko \& Lutsenko, 2017)

The minimum distance both for Hamming and Euclidean methods is reached for Scrum project management methodology. So, Scrum methodology is recommended as a basis for the further methodology formation. Other closest methodologies are XP and Kanban. These results indicate that for the given project agile project management methodologies are more suitable than plan-driven approaches (PMBOK, ISO21500, PRINCE2, and SWEBOK).

\subsection{Alternative methodologies formation}

An expert has formed two alternative specialized methodologies for the PMGuide software development project. An expert here is a person who has a comprehensive knowledge of methodologies included in GBOK.

The first methodology was created by modification of Scrum project management methodology (the primary approach).

For the second alternative, an expert has selected DSDM as a basis (other famous methodology from the agile family) and supplemented it by components from PRINCE2 and Scrum methodologies.

Both specialized methodologies have their composition of project management values and principles, project life cycle, organizational structure, roles and responsibilities, processes, and practices (Table 3 ). 
Table 2: Calculation of the total weighted Hamming and Euclidean distances

\begin{tabular}{ccc}
\hline Approach & Hamming distance & Euclidean distance \\
& $d_{\alpha}\left(A_{r}, B\right)=\sum_{k=1}^{K} \alpha_{k} \sum_{i=1}^{I}\left|d_{k}\left(A_{r}, B\right)\right|$ & $e_{\alpha}\left(A_{r}, B\right)=\sum_{k=1}^{K} \alpha_{k} \sqrt{\sum_{i=1}^{I}\left(d_{k}\left(A_{r}, B\right)\right)^{2}}$ \\
\hline PMBOK, $A_{1}$ & 0.608 & 0.588 \\
ISO21500, $A_{2}$ & 0.608 & 0.588 \\
PRINCE2, $A_{3}$ & 0.663 & 0.643 \\
SWEBOK, $A_{4}$ & 0.578 & 0.558 \\
Scrum, $A_{5}$ & 0.139 & 0.139 \\
XP, $A_{6}$ & 0.295 & 0.292 \\
Kanban, $A_{7}$ & 0.365 & 0.340 \\
\hline
\end{tabular}

Table 3: Alternative specialized project management methodologies

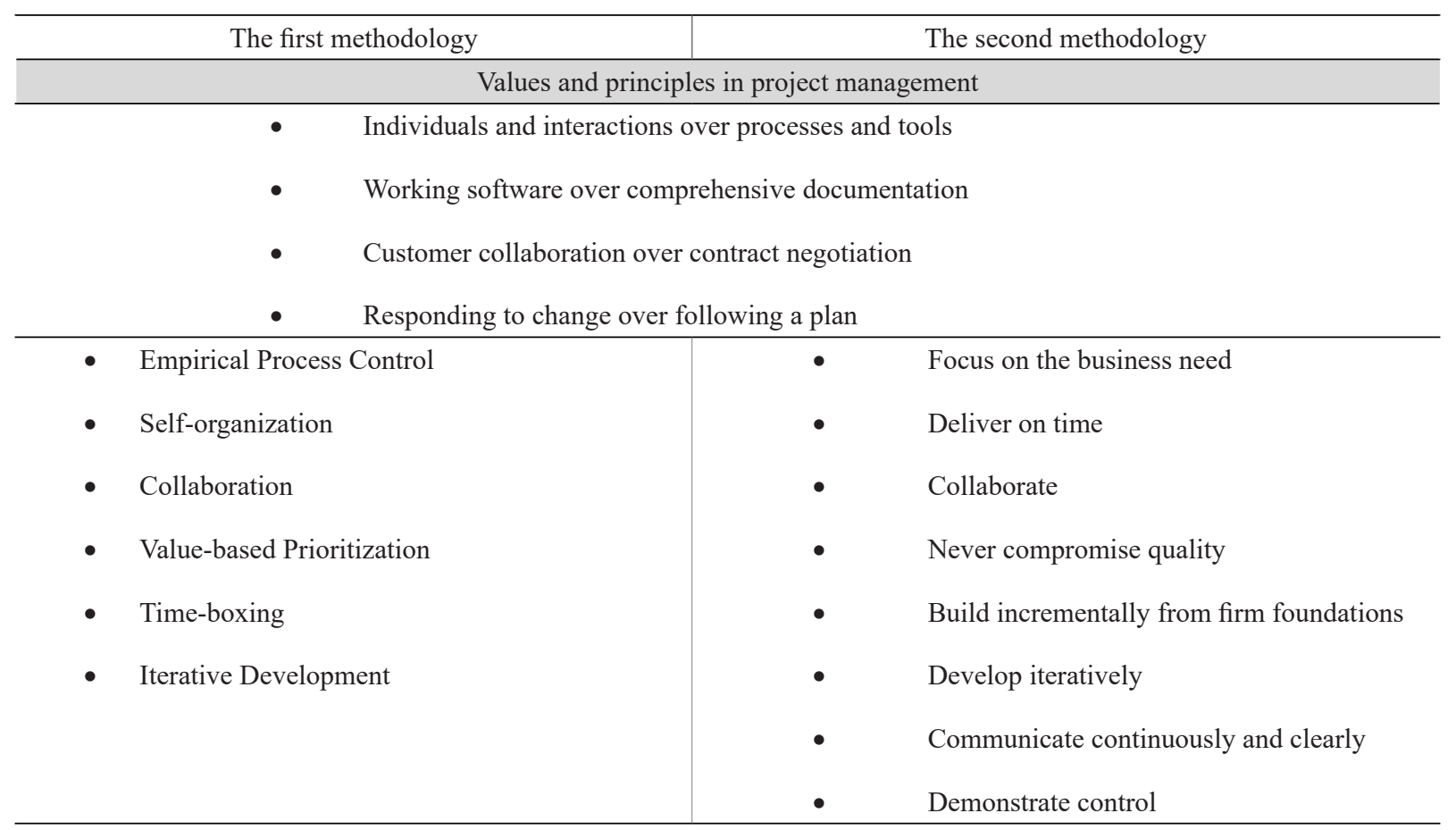


Table 3: Alternative specialized project management methodologies (continued)

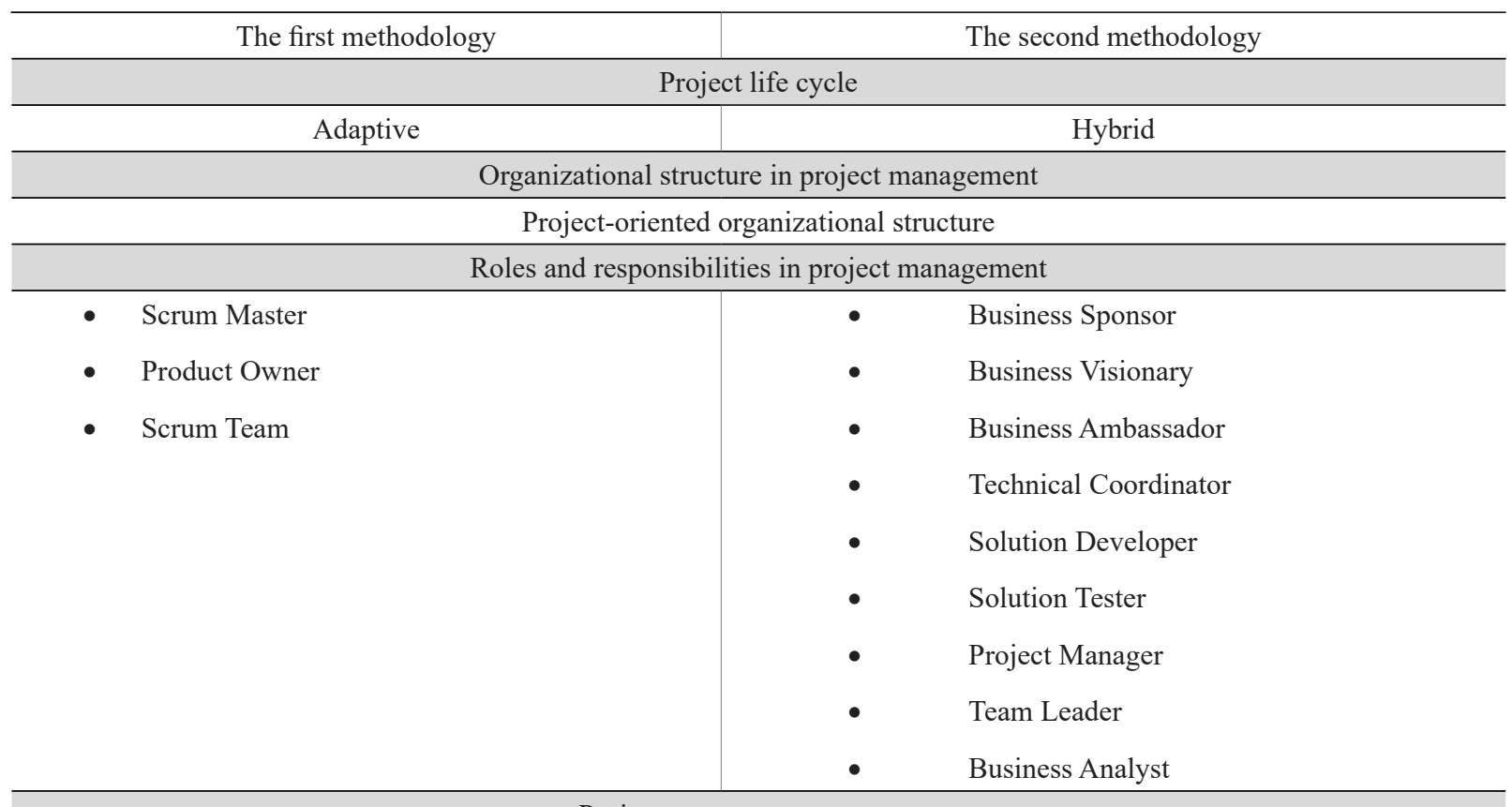

Project management processes

- $\quad$ Develop Epic(s)

- Create Prioritized Product Backlog

- Conduct Release Planning

- Create User Stories

- Approve, Estimate, and Commit User Stories

- $\quad$ Create Tasks

- Estimate Tasks

- Create Sprint Backlog

- Conduct Daily Standup

- Groom Prioritized Product Backlog

- Demonstrate and Validate Sprint

- Retrospect Sprint

- $\quad$ Ship Deliverables

- Retrospect Project
- Capture previous lessons

- Prepare the outline Business Case

- Producing the Business Case

- Producing the Prioritized Requirement List

- Producing the Solution Architecture Definition

- Producing the Development Approach Definition

- Producing the delivery plan

- Creating the Timebox Plan

- Revisiting the Prioritized Requirements List

- Review of the Business Case

- Timebox Review Record

- Project Review Report

- Benefits Assessment

- Conduct Daily Standup

\section{Project management practices}

- $\quad$ The Facilitated Workshop

- MoSCoW prioritization

- Iterative development

- $\quad$ Timeboxing

- Inspections 
Values and principles in project management. The four core values of Agile manifesto underlie both the first and the second alternative methodologies. Beside them, the first methodology has in its foundation six Scrum principles, while the second one relies on eight principles of DSDM methodology (Table 3).

Project life cycle. The first methodology assumes an adaptive project life cycle implementation. This project life cycle is the most consistent with Scrum methodology. For the second methodology, an expert has selected the hybrid project life cycle that implies the simultaneous usage of adaptive and predictive approaches during a project life cycle (PMI, 2018). This option is typical for the situation when the team gradually moves to agile methodologies and uses some of their best practices (e.g., short iterations, daily meetings, and retrospectives) but other aspects of the project, such as preliminary assessment, job assignment, and tracking progress, are still performed according to predictive approaches.

Organizational structure in project management. For both methodologies the project-oriented organizational structure is advisable. This structure fits the best selected agile values and principles, and project life cycles.

Roles and responsibilities in project management. The first methodology assumes the application of Scrum roles and responsibilities. The second methodology prescribes to team members the DSDM roles and responsibilities (Table 3 ).

Project management processes. For the first methodology, an expert has selected 14 processes of Scrum methodology (SBoK version). The second methodology has been formed using processes of DSDM, PRINCE2 and Scrum methodologies. Table 3 shows complete lists of methodologies processes.

Project management practices. Both methodologies involve the same set of DSDM and FDD project management practices (Table 3 ).

\subsection{Methodology selection}

\subsubsection{The first methodology estimation}

TThe methodology estimation assumes the definition of three core measures associated with its implementation::

- $\quad$ project management laboriousness;

- project management cost;

- $\quad$ project management risks.

For the first two measures calculation, it is necessary to define all project management processes performers, their hourly rates, and, approximately, how long they might be involved in the processes' execution.

Table 4 performs all team members, needed for the first methodology implementation, and their hourly rates. The role and responsibilities of Product Owner are delegated to the Customer representative.

Table 5 lists the selected management processes, their planned performers and approximate laboriousness estimates. According to the method of methodology synthesis (Kononenko, Aghaee, \& Lutsenko, 2016), the laboriousness is represented in the form of triangular fuzzy values. A cost per performer estimate represents the multiplication of the performer laboriousness estimate by his hourly rate.

The total process laboriousness equals the sum of all its performers' laboriousness estimates. The process cost equals the sum of all its costs per performers' estimates.

The total project management laboriousness represents the total of all processes laboriousness, while its total cost equals the sum of all processes costs, respectively.

The project management laboriousness for the first methodology equals $<226.5,295.5,339.5>$ man-hours, its cost $-\$<1006.25,1311.75,1507.25>$.

The scale for evaluating the consequences of the risk events occurrence is given in Table 6. Risk events associated with the methodology application, as well as their assessments are presented in Table 7.

Table 4: Project team members' roles and hourly rates (the first methodology)

\begin{tabular}{lc}
\hline \multicolumn{1}{c}{ Team member } & Hourly rate*, \$/hour \\
\hline Product Owner & 4 \\
Scrum Master & 6 \\
& Development team \\
Middle Developer & 7 \\
Junior Developer & 4 \\
QA & 3 \\
Designer & 2.5 \\
\hline
\end{tabular}

*Hourly rates are common for Ukraine considering the position and experience of the specialist as of December 2018. Source: https://jobs.dou.ua/salaries 
Table 5: Project management laboriousness and cost estimation (the first methodology)

\begin{tabular}{|c|c|c|c|c|c|}
\hline Process & Performer & & $\begin{array}{l}\text { Laboriousness } \\
\text { estimate, } \mathrm{T} \text {, } \\
\text { man-hours }\end{array}$ & $\begin{array}{l}\text { Hourly rate, } \\
\$ / \text { hour }\end{array}$ & $\begin{array}{l}\text { Cost estimate } \\
\text { (T*Hourly rate), } \\
\text { C, } \$\end{array}$ \\
\hline \multirow{7}{*}{$\begin{array}{l}\text { 8.4 Develop } \\
\text { Epic(s) }\end{array}$} & Product Owner & & $<2,4,4>$ & 4 & $<8,16,16>$ \\
\hline & Scrum Master & & $<1,1.5,2>$ & 6 & $<6,9,12>$ \\
\hline & Middle Developer & & $<1,1.5,2>$ & 7 & $<7,10.5,14>$ \\
\hline & Junior Developer & & $<1,1.5,2>$ & 4 & $<4,6,8>$ \\
\hline & QA & & $<1,1.5,2>$ & 3 & $<3,4.5,6>$ \\
\hline & Designer & & $<1,1.5,2>$ & 2.5 & $<2.5,3.75,5>$ \\
\hline & & Total & $<7,11.5,14>$ & - & $<30.5,49.75,61>$ \\
\hline \multirow{7}{*}{$\begin{array}{l}8.5 \text { Create } \\
\text { Prioritized } \\
\text { Product } \\
\text { Backlog }\end{array}$} & Product Owner & & $<2,2,3>$ & 4 & $<8,8,12>$ \\
\hline & Scrum Master & & $<2,2,3>$ & 6 & $<12,12,18>$ \\
\hline & Middle Developer & & $<2,2,3>$ & 7 & $<14,14,21>$ \\
\hline & Junior Developer & & $<2,2,3>$ & 4 & $<8,8,12>$ \\
\hline & QA & & $<2,2,3>$ & 3 & $<6,6,9>$ \\
\hline & Designer & & $<2,2,3>$ & 2.5 & $<5,5,7.5>$ \\
\hline & & Total & $<12,12,18>$ & - & $<53,53,79.5>$ \\
\hline \multirow{7}{*}{$\begin{array}{l}8.6 \text { Conduct } \\
\text { Release Plan- } \\
\text { ning }\end{array}$} & Product Owner & & $<1,1.5,2>$ & 4 & $<4,6,8>$ \\
\hline & Scrum Master & & $<1,1.5,2>$ & 6 & $<6,9,12>$ \\
\hline & Middle Developer & & $<1,1.5,2>$ & 7 & $<7,10.5,14>$ \\
\hline & Junior Developer & & $<1,1.5,2>$ & 4 & $<4,6,8>$ \\
\hline & QA & & $<1,1.5,2>$ & 3 & $<3,4.5,6>$ \\
\hline & Designer & & $<1,1.5,2>$ & 2.5 & $<2.5,3.75,5>$ \\
\hline & & Total & $<6,9,12>$ & - & $<26.5,39.75,53>$ \\
\hline \multirow{7}{*}{$\begin{array}{l}9.1 \text { Create } \\
\text { User Stories }\end{array}$} & Product Owner & & $<6,8,8>$ & 4 & $<24,32,32>$ \\
\hline & Scrum Master & & $<6,8,8>$ & 6 & $<36,48,48>$ \\
\hline & Middle Developer & & $<6,8,8>$ & 7 & $<42,56,56>$ \\
\hline & Junior Developer & & $<6,8,8>$ & 4 & $<24,32,32>$ \\
\hline & QA & & $<6,8,8>$ & 3 & $<18,24,24>$ \\
\hline & Designer & & $<6,8,8>$ & 2.5 & $<15,20,20>$ \\
\hline & Total & & $36,48,48>$ & - & $<159,212,212>$ \\
\hline
\end{tabular}


Table 5: Project management laboriousness and cost estimation (the first methodology) (continued)

\begin{tabular}{|c|c|c|c|c|}
\hline \multirow{7}{*}{$\begin{array}{l}\text { 9.2 Approve, } \\
\text { Estimate, and } \\
\text { Commit User } \\
\text { Stories }\end{array}$} & Product Owner & $<1.5,1.5,2.5>$ & 4 & $<6,6,10>$ \\
\hline & Scrum Master & $<1.5,1.5,2.5>$ & 6 & $<6,9,15>$ \\
\hline & Middle Developer & $<1.5,1.5,2.5>$ & 7 & $<10.5,10.5,17.5>$ \\
\hline & Junior Developer & $<1.5,1.5,2.5>$ & 4 & $<6,6,10>$ \\
\hline & QA & $<1.5,1.5,2.5>$ & 3 & $<4.5,4.5,7.5>$ \\
\hline & Designer & $<1.5,1.5,2.5>$ & 2.5 & $<3.75,3.75,6.25>$ \\
\hline & Total & $<9,9,15>$ & - & $<39.75,39.75,66.25>$ \\
\hline \multirow{7}{*}{$\begin{array}{l}9.3 \text { Create } \\
\text { Tasks }\end{array}$} & Product Owner & $<3,4.5,6>$ & 4 & $<12,18,24>$ \\
\hline & Scrum Master & $<3,4.5,6>$ & 6 & $<18,27,36>$ \\
\hline & Middle Developer & $<3,4.5,6>$ & 7 & $<21,31.5,42>$ \\
\hline & Junior Developer & $<3,4.5,6>$ & 4 & $<12,18,24>$ \\
\hline & QA & $<3,4.5,6>$ & 3 & $<9,13.5,18>$ \\
\hline & Designer & $<3,4.5,6>$ & 2.5 & $<7.5,11.25,15>$ \\
\hline & Total & $<18,27,36>$ & - & $<79.5,119.25,159>$ \\
\hline \multirow{7}{*}{$\begin{array}{l}9.4 \text { Estimate } \\
\text { Tasks }\end{array}$} & Product Owner & $<1.5,2,2.5>$ & 4 & $<6,8,10>$ \\
\hline & Scrum Master & $<1.5,2,2.5>$ & 6 & $<9,12,15>$ \\
\hline & Middle Developer & $<1.5,2,2.5>$ & 7 & $<10.5,14,17.5>$ \\
\hline & Junior Developer & $<1.5,2,2.5>$ & 4 & $<6,8,10>$ \\
\hline & QA & $<1.5,2,2.5>$ & 3 & $<4.5,6,7.5>$ \\
\hline & Designer & $<1.5,2,2.5>$ & 2.5 & $<3.75,5,6.25>$ \\
\hline & Total & $<9,12,15>$ & - & $<39.75,53,66.25>$ \\
\hline \multirow{7}{*}{$\begin{array}{l}\text { 9.5 Create } \\
\text { Sprint Back- } \\
\text { log }\end{array}$} & Product Owner & $<3,4.5,4.5>$ & 4 & $<12,18,18>$ \\
\hline & Scrum Master & $<3,4.5,4.5>$ & 6 & $<18,27,27>$ \\
\hline & Middle Developer & $<3,4.5,4.5>$ & 7 & $<21,31.5,31.5>$ \\
\hline & Junior Developer & $<3,4.5,4.5>$ & 4 & $<12,18,18>$ \\
\hline & QA & $<3,4.5,4.5>$ & 3 & $<9,13.5,13.5>$ \\
\hline & Designer & $<3,4.5,4.5>$ & 2.5 & $<7.5,11.25,11.25>$ \\
\hline & Total & $<18,27,27>$ & - & $<79.5,119.25,119.25>$ \\
\hline \multirow{6}{*}{$\begin{array}{l}\text { 10.2 Conduct } \\
\text { Daily Standup }\end{array}$} & Scrum Master & $<7.5,8,8.5>$ & 6 & $<45,48,51>$ \\
\hline & Middle Developer & $<7.5,8,8.5>$ & 7 & $<52.5,56,59.5>$ \\
\hline & Junior Developer & $<7.5,8,8.5>$ & 4 & $<30,32,34>$ \\
\hline & QA & $<7.5,8,8.5>$ & 3 & $<22.5,34,25.5>$ \\
\hline & Designer & $<7.5,8,8.5>$ & 2.5 & $<18.75,20,21.25>$ \\
\hline & Total & $<37.5,40,42.5>$ & - & $<168.75,180,191.25>$ \\
\hline \multirow{7}{*}{$\begin{array}{l}10.3 \text { Groom } \\
\text { Prioritized } \\
\text { Product } \\
\text { Backlog }\end{array}$} & Product Owner & $<4,6,8>$ & 4 & $<16,24,32>$ \\
\hline & Scrum Master & $<1.5,2,3>$ & 6 & $<9,12,18>$ \\
\hline & Middle Developer & $<1.5,2,3>$ & 7 & $<10.5,14,21>$ \\
\hline & Junior Developer & $<1.5,2,3>$ & 4 & $<6,8,12>$ \\
\hline & QA & $<1.5,2,3>$ & 3 & $<4.5,6,9>$ \\
\hline & Designer & $<1.5,2,3>$ & 2.5 & $<3.75,5,7.5>$ \\
\hline & Total & $<11.5,16,23>$ & - & $<49.75,69,99.5>$ \\
\hline
\end{tabular}


Table 5: Project management laboriousness and cost estimation (the first methodology) (continued)

\begin{tabular}{|c|c|c|c|c|}
\hline \multirow{7}{*}{$\begin{array}{l}\text { 11.2 Demon- } \\
\text { strate and Val- } \\
\text { idate Sprint }\end{array}$} & Product Owner & $<4.5,6,6>$ & 4 & $<18,24,24>$ \\
\hline & Scrum Master & $<4.5,6,6>$ & 6 & $<27,36,36>$ \\
\hline & Middle Developer & $<4.5,6,6>$ & 7 & $<31.5,42,42>$ \\
\hline & Junior Developer & $<4.5,6,6>$ & 4 & $<18,24,24>$ \\
\hline & QA & $<4.5,6,6>$ & 3 & $<13.5,18,18>$ \\
\hline & Designer & $<4.5,6,6>$ & 2.5 & $<11.25,15,15>$ \\
\hline & Total & $<27,36,36>$ & - & $<119.25,159,159>$ \\
\hline \multirow{6}{*}{$\begin{array}{l}\text { 11.3 Retro- } \\
\text { spect Sprint }\end{array}$} & Scrum Master & $<4.5,6,6>$ & 6 & $<27,36,36>$ \\
\hline & Middle Developer & $<4.5,6,6>$ & 7 & $<31.5,42,42>$ \\
\hline & Junior Developer & $<4.5,6,6>$ & 4 & $<18,24,24>$ \\
\hline & QA & $<4.5,6,6>$ & 3 & $<13.5,18,18>$ \\
\hline & Designer & $<4.5,6,6>$ & 2.5 & $<11.25,15,15>$ \\
\hline & Total & $<22.5,30,30>$ & - & $<101.25,135,135>$ \\
\hline \multirow{3}{*}{$\begin{array}{l}\text { 12.1 Ship } \\
\text { Deliverables }\end{array}$} & Product Owner & $<2,3,4>$ & 4 & $<8,12,16>$ \\
\hline & Scrum Master & $<2,3,4>$ & 6 & $<12,18,24>$ \\
\hline & Total & $<4,6,8>$ & - & $<20,30,40>$ \\
\hline \multirow{8}{*}{$\begin{array}{l}\text { 12.2 Retro- } \\
\text { spect Project }\end{array}$} & Product Owner & $<1.5,2,2.5>$ & 4 & $<6,8,10>$ \\
\hline & Scrum Master & $<1.5,2,2.5>$ & 6 & $<9,12,15>$ \\
\hline & Middle Developer & $<1.5,2,2.5>$ & 7 & $<10.5,14,17.5>$ \\
\hline & Junior Developer & $<1.5,2,2.5>$ & 4 & $<6,8,10>$ \\
\hline & QA & $<1.5,2,2.5>$ & 3 & $<4.5,6,7.5>$ \\
\hline & Designer & $<1.5,2,2.5>$ & 2.5 & $<3.75,5,6.25>$ \\
\hline & Total & $<9,12,15>$ & - & $<39.75,53,66.25>$ \\
\hline & Methodology total & $<226.5,295.5,339.5>$ & - & $\begin{array}{c}<1006.25,1311.75 \\
1507.25>\end{array}$ \\
\hline
\end{tabular}

Table 6: Evaluation of risk events consequences

\begin{tabular}{l|c}
\hline \multicolumn{1}{c}{ Negative consequences } & Points \\
\hline $\begin{array}{l}\text { Impacts that lead to the termination or complete failure of the project } \\
\begin{array}{l}\text { Impacts that lead to extremely significant project delays, budget overruns, deterioration of the project } \\
\text { product quality }\end{array}\end{array}$ & 10 \\
\hline $\begin{array}{l}\text { Impacts that lead to significant project delays, budget overruns, deterioration of the project product } \\
\text { quality }\end{array}$ & $6-9$ \\
\hline $\begin{array}{l}\text { Impacts that lead to not very significant project delays, budget overruns, deterioration of the project } \\
\text { product quality }\end{array}$ & $4-5$ \\
\hline $\begin{array}{l}\text { Impacts that lead to slightly noticeable delays in the project, budget overrun, deterioration of the project } \\
\text { product quality }\end{array}$ & $2-3$ \\
\hline $\begin{array}{l}\text { Negative effects are almost invisible } \\
\text { No negative effects }\end{array}$ & 1 \\
\hline
\end{tabular}


Table 7: The assessment of risks associated with the first methodology application

\begin{tabular}{lccc}
\hline \multicolumn{1}{c}{ Risk event } & $\begin{array}{c}\text { The occurrence } \\
\text { probability, P }\end{array}$ & $\begin{array}{c}\text { The occurrence } \\
\text { consequences, }, \\
\text { points },\end{array}$ & Risk assessment, \\
\hline $\begin{array}{l}\text { Project participants do not accept Scrum values } \\
\text { and principles }\end{array}$ & $<0.05,0.05,0.05>$ C, points \\
\hline $\begin{array}{l}\text { Team members don't understand/accept roles and } \\
\text { responsibilities prescribed them by Scrum meth- } \\
\text { odology }\end{array}$ & $<0.1,0.1,0.1>$ & $<7,8,8>$ & $<0.35,0.4,0.4>$ \\
$\begin{array}{l}\text { The lack of Customer's work experience as Prod- } \\
\text { uct Owner }\end{array}$ & $<0.2,0.2,0.2>$ & $<5,8,8>$ & $<0.7,0.8,0.8>$ \\
\hline $\begin{array}{l}\text { Contradictions between the standards and regula- } \\
\text { tions of the contracting and / or executing organi- }\end{array}$ & $<0.05,0.1,0.15>$ & $<5,6,8>$ & $<1,1,1.2>$ \\
$\begin{array}{l}\text { zation(s) and the methodology } \\
\text { The Product Owner involvement in the project is } \\
\text { insufficient for an optimal solution development }\end{array}$ & $<0.4,0.4,0.4>$ & $<7,8,8>$ & $<0.25,0.6,1.2>$ \\
$\begin{array}{l}\text { Project team self-organization and self-coordina- } \\
\text { tion are insufficient to work effectively according }\end{array}$ & $<0.3,0.3,0.3>$ & $<7,8,8>$ & $<2.8,3.2,3.2>$ \\
$\begin{array}{l}\text { Scrum } \\
\text { Wrong prioritization of the product backlog }\end{array}$ & $<0.35,0.35,0.35>$ & $<5,5,6>$ & $<1.75,1.75,2.1>$ \\
$\begin{array}{l}\text { Ineffective sprint planning } \\
\text { The product inefficiency as a result of poor } \\
\text { pre-project research and planning }\end{array}$ & $<0.4,0.4,0.4>$ & $<5,6,7>$ & $<2,2.4,2.8>$ \\
\hline \begin{tabular}{l} 
Total risk assessment \\
\hline
\end{tabular} & $<0.5,0.5,0.5>$ & $<7,8,9>$ & $<3.5,4,4.5>$ \\
\hline
\end{tabular}

The first methodology risks assessment equals $<14.45,16.55,18.6>$.

Table 8: Project team members' roles and hourly rates (the second methodology)

\begin{tabular}{lc}
\hline \multicolumn{1}{c}{ Project team member } & $\begin{array}{c}\text { Hourly rate, } \\
\text { \$/hour }\end{array}$ \\
\hline Business Ambassador (Business Visionary) & 4 \\
Project Manager (Team Leader) & 6 \\
\hline \multicolumn{2}{c}{ Development team } \\
\hline Middle Developer (Technical Coordinator, Solution Developer) & 7 \\
Junior Developer (Solution Developer) & 4 \\
QA (Business Analyst, Solution Tester) & 5 \\
Designer & 2.5 \\
\hline
\end{tabular}




\subsubsection{The second methodology estimation}

The second methodology prescribes its roles to project participants. Table 8 shows which roles and hourly rates were assigned to team members. The project customer performs the role of Business Sponsor; the customer rep- resentative fulfills Business Ambassador and Business Visionary roles.

Table 9 lists the second methodology's management processes, their performers, laboriousness, and cost.

Table 9: Project management laboriousness and cost estimation (the second methodology)

\begin{tabular}{|c|c|c|c|c|}
\hline Process & Performer & $\begin{array}{c}\text { Laboriousness, } \mathrm{T}, \\
\text { man-hours }\end{array}$ & $\begin{array}{c}\text { Hourly rate, } \\
\$ / \text { hour }\end{array}$ & Cost ( $\mathrm{T}^{*}$ Hourly rate), C, $\$$ \\
\hline \multirow{6}{*}{$\begin{array}{l}\text { 12.4.2 Capture } \\
\text { previous lessons } \\
\text { (PRINCE2) }\end{array}$} & Project Manager & $<1.5,2,2.5>$ & 6 & $<9,12,15>$ \\
\hline & Middle Developer & $<1.5,2,2.5>$ & 7 & $<10.5,14,17.5>$ \\
\hline & Junior Developer & $<1.5,2,2.5>$ & 4 & $<6,8,10>$ \\
\hline & QA & $<1.5,2,2.5>$ & 5 & $<7.5,10,12.5>$ \\
\hline & Designer & $<1.5,2,2.5>$ & 2.5 & $<3.75,5,6.25>$ \\
\hline & Total & $<7.5,10,12.5>$ & - & $<36.75,49,61.25>$ \\
\hline \multirow{3}{*}{$\begin{array}{l}\text { 12.4.4 Prepare the } \\
\text { outline Business } \\
\text { Case (PRINCE2) }\end{array}$} & QA & $<2,4,5>$ & 5 & $<10,20,25>$ \\
\hline & Business Ambassador & $<0.5,1,1.5>$ & 4 & $<2,4,6>$ \\
\hline & Total & $<2.5,5,6.5>$ & - & $<12,24,31>$ \\
\hline \multirow{3}{*}{$\begin{array}{l}8.2 .2 \text { Producing } \\
\text { the Business Case } \\
\text { (DSDM) }\end{array}$} & QA & $<4,6,6>$ & 5 & $<20,30,30>$ \\
\hline & Business Ambassador & $<2,4,4>$ & 4 & $<8,16,16>$ \\
\hline & Total & $<6,10,10>$ & - & $<28,46,46>$ \\
\hline \multirow{3}{*}{$\begin{array}{l}\text { 8.2.3 Producing the } \\
\text { Prioritized Require- } \\
\text { ment List (DSDM) }\end{array}$} & QA & $<4,4,5>$ & 5 & $<20,20,25>$ \\
\hline & Business Ambassador & $<4,4,5>$ & 4 & $<16,16,20>$ \\
\hline & Total & $<8,8,10>$ & - & $<36,36,45>$ \\
\hline \multirow{4}{*}{$\begin{array}{l}\text { 8.2.4 Producing the } \\
\text { Solution Archi- } \\
\text { tecture Definition } \\
\text { (DSDM) }\end{array}$} & QA & $<2,4,4>$ & 5 & $<10,20,20>$ \\
\hline & Business Ambassador & $<0.5,1,1.5>$ & 4 & $<2,4,6>$ \\
\hline & Middle Developer & $<3,4,6>$ & 7 & $<21,28,42>$ \\
\hline & Total & $<5.5,9,11.5>$ & - & $<33,52,68>$ \\
\hline \multirow{3}{*}{$\begin{array}{l}8.2 .5 \text { Producing } \\
\text { the Development } \\
\text { Approach Definition } \\
\text { (DSDM) }\end{array}$} & Middle Developer & $<2,3,4>$ & 7 & $<14,21,28>$ \\
\hline & Project Manager & $<0.5,0.5,1>$ & 6 & $<3,3,6>$ \\
\hline & Total & $<2.5,3.5,5>$ & - & $<17,24,34>$ \\
\hline \multirow{4}{*}{$\begin{array}{l}\text { 8.2.6 Producing } \\
\text { the delivery plan } \\
\text { (DSDM) }\end{array}$} & Project Manager & $<2,2,3>$ & 6 & $<12,12,18>$ \\
\hline & Business Ambassador & $<0.5,0.5,1>$ & 4 & $<2,2,4>$ \\
\hline & Middle Developer & $<0.5,0.5,1>$ & 7 & $<3.5,3.5,7>$ \\
\hline & Total & $<3,3,5>$ & - & $<17.5,17.5,29>$ \\
\hline
\end{tabular}


Table 9: Project management laboriousness and cost estimation (the second methodology) (continued)

\begin{tabular}{|c|c|c|c|c|}
\hline Process & Performer & $\begin{array}{l}\text { Laboriousness, } \mathrm{T}, \\
\text { man-hours }\end{array}$ & $\begin{array}{l}\text { Hourly rate, } \\
\$ / \text { hour }\end{array}$ & Cost (T*Hourly rate), $\mathrm{C}, \$$ \\
\hline \multirow{7}{*}{$\begin{array}{l}8.2 .11 \text { Creating } \\
\text { the Timebox Plan } \\
\text { (DSDM) }\end{array}$} & Business Ambassador & $<6,8,9>$ & 4 & $<24,32,36>$ \\
\hline & Project Manager & $<6,8,9>$ & 6 & $<36,48,54>$ \\
\hline & Middle Developer & $<6,8,9>$ & 7 & $<42,56,63>$ \\
\hline & Junior Developer & $<6,8,9>$ & 4 & $<24,32,36>$ \\
\hline & QA & $<6,8,9>$ & 5 & $<30,40,45>$ \\
\hline & Designer & $<6,8,9>$ & 2.5 & $<15,20,22.5>$ \\
\hline & Total & $<36,48,54>$ & - & $<171,228,256.5>$ \\
\hline \multirow{7}{*}{$\begin{array}{l}8.2 .3 \text { Revisiting the } \\
\text { Prioritized Require- } \\
\text { ments List (DSDM) }\end{array}$} & Business Ambassador & $<6,9,12>$ & 4 & $<24,36,48>$ \\
\hline & Project Manager & $<12,15,18>$ & 6 & $<72,90,108>$ \\
\hline & Middle Developer & $<12,15,18>$ & 7 & $<84,105,126>$ \\
\hline & Junior Developer & $<12,15,18>$ & 4 & $<48,60,72>$ \\
\hline & QA & $<12,15,18>$ & 5 & $<60,75,90>$ \\
\hline & Designer & $<12,15,18>$ & 2.5 & $<30,37.5,45>$ \\
\hline & Total & $<66,84,102>$ & - & $<318,403.5,489>$ \\
\hline \multirow{3}{*}{$\begin{array}{l}8.2 .2 \text { Review of } \\
\text { the Business Case } \\
\text { (DSDM) }\end{array}$} & QA & $<6,6,8>$ & 5 & $<30,30,40>$ \\
\hline & $\begin{array}{r}\text { Business Ambas- } \\
\text { sador }\end{array}$ & $<2,4,4>$ & 4 & $<8,16,16>$ \\
\hline & Total & $<8,12,12>$ & - & $<38,46,56>$ \\
\hline \multirow{7}{*}{$\begin{array}{l}\text { 8.2.12 Timebox Re- } \\
\text { view Record (DSDM) }\end{array}$} & Business Ambassador & $<4.5,6,9>$ & 4 & $<18,24,36>$ \\
\hline & Project Manager & $<4.5,6,9>$ & 6 & $<27,36,54>$ \\
\hline & Middle Developer & $<4.5,6,9>$ & 7 & $<31.5,42,63>$ \\
\hline & Junior Developer & $<4.5,6,9>$ & 4 & $<18,24,36>$ \\
\hline & QA & $<4.5,6,9>$ & 5 & $<22.5,30,45>$ \\
\hline & Designer & $<4.5,6,9>$ & 2.5 & $<11.25,15,22.5>$ \\
\hline & Total & $<27,36,54>$ & - & $\begin{array}{r}<128.25,171, \\
256.5>\end{array}$ \\
\hline \multirow{7}{*}{$\begin{array}{l}\text { 8.2.13 Project Review } \\
\text { Report (DSDM) }\end{array}$} & Business Ambassador & $<1,2,3>$ & 4 & $<4,8,12>$ \\
\hline & Project Manager & $<1,2,3>$ & 6 & $<6,12,18>$ \\
\hline & Middle Developer & $<1,2,3>$ & 7 & $<7,14,21>$ \\
\hline & Junior Developer & $<1,2,3>$ & 4 & $<4,8,12>$ \\
\hline & QA & $<1,2,3>$ & 5 & $<5,10,15>$ \\
\hline & Designer & $<1,2,3>$ & 2.5 & $<2.5,5,7.5>$ \\
\hline & Total & $<6,12,18>$ & - & $<28.5,57,85.5>$ \\
\hline \multirow{3}{*}{$\begin{array}{l}\text { 8.2.14 Benefits Assess- } \\
\text { ment (DSDM) }\end{array}$} & QA & $<2,4,4>$ & 5 & $<10,20,20>$ \\
\hline & $\begin{array}{r}\text { Business Ambas- } \\
\text { sador }\end{array}$ & $<2,4,4>$ & 4 & $<8,16,16>$ \\
\hline & Total & $<4,8,8>$ & - & $<18,36,36>$ \\
\hline
\end{tabular}


Table 9: Project management laboriousness and cost estimation (the second methodology) (continued)

\begin{tabular}{|c|c|c|c|c|}
\hline \multirow{6}{*}{$\begin{array}{l}10.2 \text { Conduct Daily } \\
\text { Meetings (Scrum) }\end{array}$} & Project Manager & $<7.5,8,8.5>$ & 6 & $<45,48,51>$ \\
\hline & Middle Developer & $<7.5,8,8.5>$ & 7 & $<52.5,56,59.5>$ \\
\hline & Junior Developer & $<7.5,8,8.5>$ & 4 & $<30,32,34>$ \\
\hline & QA & $<7.5,8,8.5>$ & 5 & $<37.5,40,42.5>$ \\
\hline & Designer & $<7.5,8,8.5>$ & 2.5 & $<18.75,20,21.25>$ \\
\hline & Total & $<37.5,40,45.5>$ & - & $\begin{array}{r}<183.75,196, \\
208.25>\end{array}$ \\
\hline Total for the methodology & & $\begin{array}{c}<219.5,286.5 \\
351>\end{array}$ & - & $\begin{array}{c}<1065.75,1386, \\
1702>\end{array}$ \\
\hline
\end{tabular}

Table 10: The assessment of risks associated with the second methodology application

\begin{tabular}{|c|c|c|c|}
\hline Risk event & $\begin{array}{l}\text { The occurrence } \\
\text { probability, } \mathrm{P}\end{array}$ & $\begin{array}{l}\text { The occur- } \\
\text { rence conse- } \\
\text { quences, C } \\
\text { (points) }\end{array}$ & $\begin{array}{l}\text { Risk assessment, } \\
\qquad \mathrm{R}=\mathrm{P}^{*} \mathrm{C}\end{array}$ \\
\hline $\begin{array}{l}\text { Project participants do not accept DSDM values and } \\
\text { principles }\end{array}$ & $<0.35,0.4,0.45>$ & $<7,8,8>$ & $<2.45,3.2,3.6>$ \\
\hline $\begin{array}{l}\text { Team members don't understand/accept roles and re- } \\
\text { sponsibilities prescribed them by DSDM }\end{array}$ & $<0.35,0.4,0.45>$ & $<7,8,8>$ & $<2.45,3.2,3.6>$ \\
\hline $\begin{array}{l}\text { The lack of customer/ his representative work experi- } \\
\text { ence as Business Sponsor/Business Visionary }\end{array}$ & $<0.2,0.2,0.2>$ & $<5,5,6>$ & $<1,1,1.2>$ \\
\hline $\begin{array}{l}\text { Contradictions between the standards and regulations of } \\
\text { the contracting and / or executing organization(s) and the } \\
\text { methodology }\end{array}$ & $<0.1,0.15,0.2>$ & $<5,6,8>$ & $<0.5,0.9,1.6>$ \\
\hline $\begin{array}{l}\text { Business Sponsor/Business Visionary involvement in the } \\
\text { project is insufficient for an optimal solution develop- } \\
\text { ment }\end{array}$ & $<0.15,0.2,0.2>$ & $<7,8,8>$ & $<1.05,1.6,1.6>$ \\
\hline $\begin{array}{l}\text { Project team self-organization and self-coordination are } \\
\text { insufficient to work effectively according DSDM }\end{array}$ & $<0.15,0.2,0.25>$ & $<7,8,8>$ & $<1.05,1.6,2>$ \\
\hline $\begin{array}{l}\text { Problems associated with assigning multiple DSDM } \\
\text { roles to one team member }\end{array}$ & $<0.5,0.5,0.57>$ & $<5,6,6>$ & $<2.5,3,3.42>$ \\
\hline Total risk assessment & & \multicolumn{2}{|c|}{$<11,14.5,17.02>$} \\
\hline
\end{tabular}

The project management laboriousness for the second methodology equals $<219.5,286.5,351>$ man-hours, its cost $-\$<1065.75,1386,1702>$.

Risk events associated with the methodology application, as well as their assessments are presented in Table 10.
Comparative charts in Figures 3-5 illustrate project management laboriousness and cost for both alternative methodologies, as well as project risks associated with their application. 


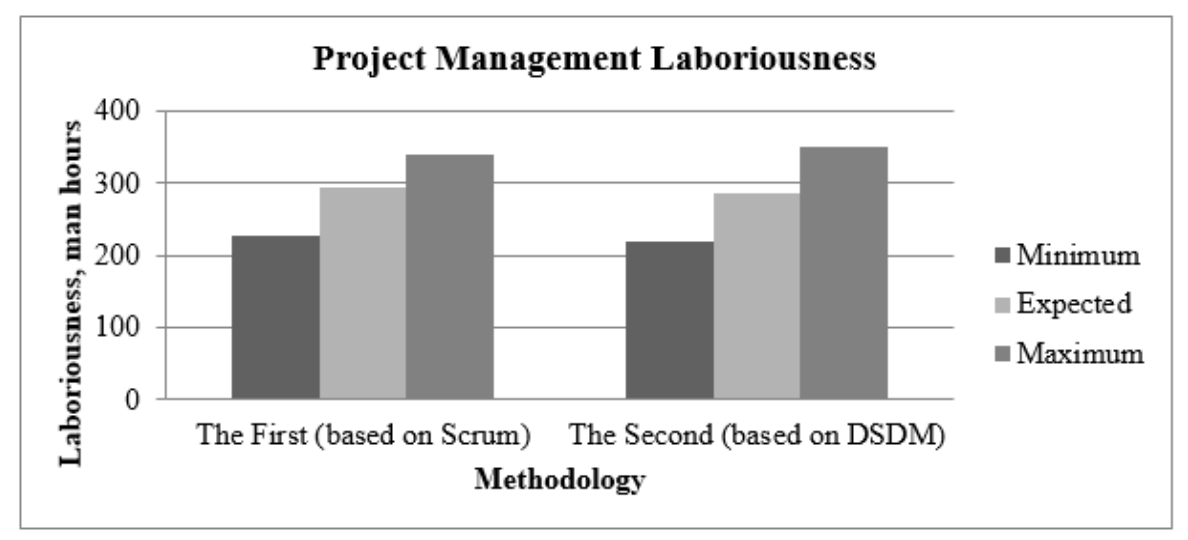

Figure 3: The project management laboriousness comparison

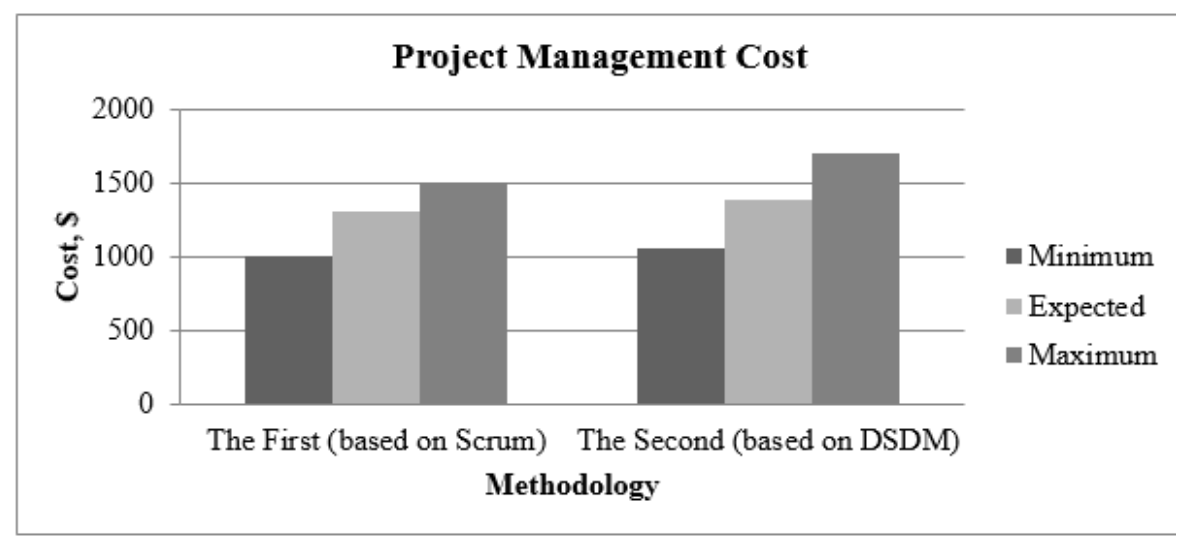

Figure 4: The project management cost comparison

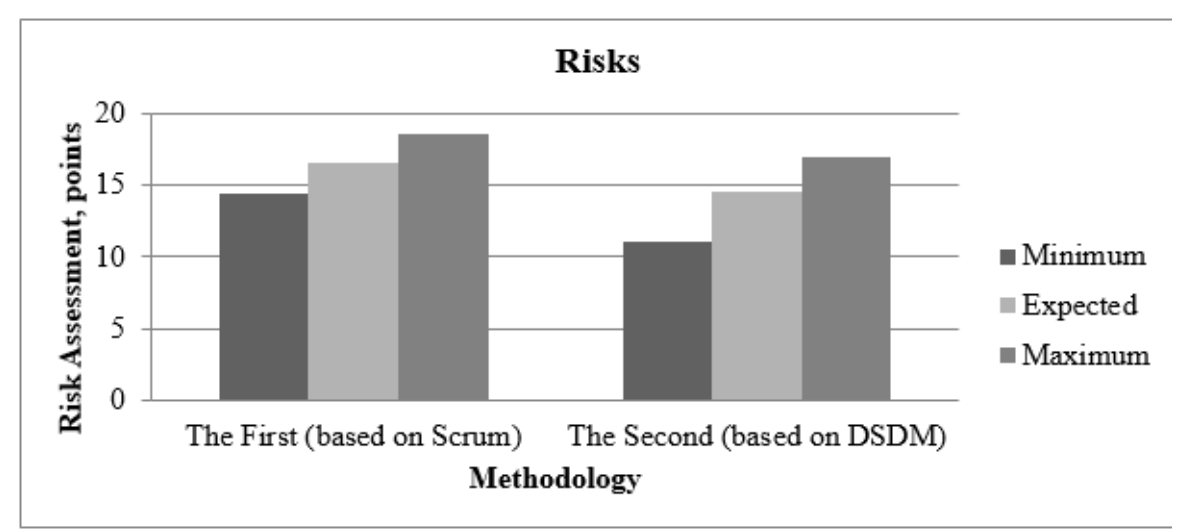

Figure 5: Risks assessments comparison 


\subsubsection{The first methodology estimation}

On this stage we reveal which methodology is the most suitable for the project, using the mathematical model described in (Kononenko, Aghaee, \& Lutsenko, 2016).

Target functions will take the form (1) - (3).

$C(X)=\langle 1006.25,1311.75,1507.25\rangle x_{1}+\langle 1065.75,1386,1702\rangle x_{2} \rightarrow \min _{X}$

$T(X)=\langle 226.5,295.5,339.5\rangle x_{1}+\langle 219.5,286.5,351\rangle x_{2} \rightarrow \min _{X}$,

$R(X)=\langle 14.45,16.55,18.6\rangle x_{1}+\langle 11,14.5,17.02\rangle x_{2} \rightarrow \min _{X}$,

where $X=\left(x_{1}, x_{2}\right), x_{h}=\{0,1\}, h=1,2, \sum_{h=1}^{H} x_{h}=1$, $x_{h}=1$, if $\mathrm{h}$-th alternative is applied, $\mathrm{x}_{\mathrm{h}}=0$ else.

The cost of project management should not exceed $\$ 1750$. It means that the cost limit is $\mathrm{C}^{\mathrm{per}}=1750 \$$ :

$$
\begin{aligned}
& C(1,0)=\langle 1006.25,1311.75,1507.25\rangle<1750, \\
& C(0,1)=\langle 1065.75,1386,1702\rangle<1750 .
\end{aligned}
$$

All alternative methodologies meet the limit.

The problem of one-criterion optimization for each target function should be solved to normalize target functions for their further comparison. But first, let us defuzzify obtained fuzzy values:

$$
\begin{gathered}
C^{d}(1,0)=\frac{1006.25+1311.75+1507.25}{3}=1275.08 . \\
C^{d}(0,1)=\frac{1065.75+1386+1702}{3}=1384.58 . \\
T^{d}(1,0)=\frac{226.5+295.5+339.5}{3}=287.17 . \\
T^{d}(0,1)=\frac{219.5+286.5+351}{3}=285.67 . \\
R^{d}(1,0)=\frac{14.45+16.55+18.6}{3}=16.53 . \\
R^{d}(0,1)=\frac{11+14.5+17.02}{3}=14.17 .
\end{gathered}
$$

$C^{d}(X), T^{d}(X), R^{d}(X)$ - defuzzification values of the project management cost, laboriousness, and risks associated with the methodology applied.

The target functions minimum values will be equal to:

$$
\begin{gathered}
C^{\mathrm{opt}}=\min \{1275.08,1384.58\}=1275.08 . \\
T^{\mathrm{opt}}=\min \{287.17,285.67\}=285.67 . \\
R^{\mathrm{opt}}=\min \{16.53,14.17\}=14.17 .
\end{gathered}
$$

Based on the results, we can calculate the target functions normalized values:

$$
\begin{aligned}
& \mathrm{C}^{\mathrm{nom}}(1,0)=\frac{\mathrm{C}^{d}(1,0)-C^{\mathrm{opt} t}}{C^{\mathrm{opt}}}=\frac{1275.08-1275.08}{1275.08}=0 . \\
& C^{\text {nom }}(0,1)=\frac{C^{d}(0,1)-C^{\text {opt }}}{C^{\text {opt }}}=\frac{1384.58-1275.08}{1275.08}=0.086 \text {. } \\
& T^{\mathrm{nom}}(1,0)=\frac{T^{d}(1,0)-T^{\mathrm{op} t}}{T^{\mathrm{opt}}}=\frac{287.17-285.67}{285.67}=0.005 . \\
& T^{\mathrm{nom}}(0,1)=\frac{T^{d}(0,1)-T^{\text {opt }}}{T^{\text {opt }}}=\frac{285 \cdot 67-285 \cdot 67}{285 \cdot 67}=0 . \\
& R^{\mathrm{norm}}(1,0)=\frac{R^{d}(1,0)-R^{\mathrm{opt}}}{R^{\mathrm{opt}}}=\frac{16.53-14.17}{14.17}=0.167 \text {. } \\
& R^{\mathrm{nom}}(0,1)=\frac{R^{d}(0,1)-R^{\text {opt }}}{R^{\mathrm{opt}}}=\frac{14 \cdot 17-14 \cdot 17}{14 \cdot 17}=0 .
\end{aligned}
$$

The minimax criterion:

$$
\begin{aligned}
& X^{\text {opt }}=\arg \min \left\{\begin{array}{l}
\max \left\{C^{\text {nom }}(1,0), T^{\text {nom }}(1,0), \mathrm{R}^{\mathrm{nom}}(1,0)\right\} \\
\max \left\{\mathrm{C}^{\mathrm{nom}}(0,1), \mathrm{T}^{\mathrm{nom}}(0,1), \mathrm{R}^{\mathrm{nom}}(0,1)\right\}
\end{array}\right\}= \\
& =\arg \min \left\{\begin{array}{l}
\max \{0,0.005,0.167\}, \\
\max \{0.086 ; 0 ; 0\}
\end{array}\right\}=\arg \min \{0.167,0.086\}=(0,1) .
\end{aligned}
$$

Thus, the second methodology, which represents a combination of DSDM, PRINCE2, and Scrum methodologies, is the most appropriate for the given project according to the minimax approach. In case of its application, the cost of project management is $\$<1065.75,1386,1702>$, its laboriousness $-<219.5,286.5,351>$ man-hours, and risks associated with its applying $-<11.0,14.5,17.02>$..

\section{Conclusions}

The results obtained in the paper show that it is important to consider specific conditions of the project and its environment solving the task of the methodology selection to improve the project performance. It is necessary to take into account that each ready-made project management methodology has its specific strengths and weaknesses, and as usual can't cover all project needs. That is why any methodology selected must be tailored to fit the project or the specialized methodology should be created.

It should be noted that an ideal methodology does not exist. The environment is constantly changing and the methodology, which was the best in some conditions, will begin to show flaws in others. However, for quasi-stationary conditions, you can choose the best option among all possible in the sense of multi-criteria choice. The Project Management Methodology Formation's Method proposed in the paper allows us to solve both tasks: 1) the readymade methodology selection, 2) the specialized methodology formation. The ready-made methodology selection task can be easily solved by any project manager on the pre-initiating project phase using the method described. It doesn't require any specific knowledge or investiga- 
tions. A project manager should only evaluate his project using questionnaires proposed and analyze the results of the method application. The specialized methodology formation task requires the person who applies the method a deep understanding of methodologies gathered in GBOK and their components. That is why these stages of the method are more suited for consulting companies and for expensive and responsible projects (for the cases when it is reasonable to involve experts).

A limitation of the method is that it is designed for the analysis of individual projects, rather than a set of projects simultaneously.

The method was applied to a project dedicated to PMGuide web application development. Scrum was defined as a basic methodology for the project as a result of the project evaluation on a special questionnaire. Then, two alternative methodologies were created and evaluated by an expert: 1) based on Scrum; 2) based on DSDM. Both methodologies are Agile. The second alternative turns out to be more expensive and labor-intensive but less risky. It was a risk that was crucial in decision-making. The pre-project phase is of great importance for the considered project and comprehensive documentation created on this stage became the main advantage of DSDM compared to Scrum. The complexity of calculations and the usage of expert evaluations can be considered as the main limitations of the proposed method. It is proposed to use the criteria of laboriousness, cost, and risks to select or form a methodology. Solving the problem, it is also necessary to take into account the influence of methodology on the quality of the project product, on economic, social, technological effects, environmental impact and possibly other effects (political, military and others). The concept of risk allows reflecting the potential problems with these effects and simplifies the task.

Therefore, a significant dependence of the results on the accuracy of the labor input, management costs, and risk estimates is considered as a disadvantage of the method.

That is why the further areas of work are 1) software development (to perform all calculations automatically with a specialized web application), 2) the experts' selection method creation (to be sure that all experts evaluations used are verified).

The complex collection of relevant project data in the pre-initialization phase could be time and cost consuming. But these expenses are justified for large, complex, expensive, and responsible projects.

The project was managed using the formed methodology. The result of the project (PMGuide web application) meets all requirements; the project is performed according to its initial time and costs limitations. The given method can be applied to form a project management methodology for any IT project.

\section{Literature}

Agile Business Consortium (2014). The DSDM Agile Project Framework. Retrieved from https://www.agilebusiness.org/page/TheDSDMAgileProjectFramework

Anderson, D. J. (2010). Kanban: Successful Evolutionary Change for Your Technology Business. Washington: Blue Hole Press. OGC (2017). Managing successful projects with PRINCE2. London: TSO.

Beck, K. (2004). Extreme Programming Explained: Embrace Change. Second Edition. Addison-Wesley Professional.

Boehm,B.\& Turner, R. (2004). Balancing agility and discipline: evaluating and integrating agile and plan-driven methods. Proceedings. 26th International Conference on Software Engineering. http://doi.org/10.1109/ICSE.2004.1317503

IEEE (2014). Guide to the software engineering body of knowledge(SWEBOKV3.0). IEEEComputerSocietyPress.335p.

Bushuev, S. D., \& Neizvestnyy, S. I. (2013). The project management methodologies genome as the universal knowledge model. Management of Development of Complex Systems, 14, 15-18.

Conforto E., Salum F., Amaral D., et al. (2014). Can Agile Project Management Be Adopted by Industries Other than Software Development? Project Management Journal, 45(3), 21-34. https://doi.org/10.1002/pmj.21410

Čelesnik, G., Radujković, M., \& Vrečko, I. (2018). Resolving Companies in Crisis: Agile Crisis Project Management. Organizacija, 51(4), 223237. http://doi.org/10.2478/orga-2018-0023

Gallup (2012). The cost of bad project management. Retrieved from https://news.gallup.com/businessjournal/152429/cost-bad-project-management.aspx

Gartner (2012). Survey shows why projects fail. Retrieved from https://www.gartner.com/en/documents/2034616

Gorakavi, P. K. (2009). Build Your Project Using Feature Driven Development. Retrieved from http:// www.ipma-usa.org/articles/A4 AboutFDD.pdf

Harvard Business Review (2011). Why your IT project may be riskier than you think, Harvard Business Review. Retrieved from https://hbr.org/2011/09/ why-your-it-project-may-be-riskier-than-you-think ISO(2012). ISO 21500:2012, Guidance on project management

Joslin, R., \& Müller, R. (2015). Relationships between a project management methodology and project success in different project governance contexts. International Journal of Project Management, 33(6), 13771392. http://doi.org/10.1016/j.ijproman.2015.03.005

Joslin, R., \& Müller, R. (2016). The impact of project methodologies on project success in different project environments. International Journal of Managing Projects in Business, 9(2), 364-388. http://doi.org/10.1108/IJMPB-03-2015-0025

Kononenko, I., Aghaee, A., \& Lutsenko, S. (2016). Application of the Project Management Methodology Synthesis Method with fuzzy input data. Eastern-European Journal of Enterprise Technologies, 2/3(80), 32-39. http://doi.org/10.15587/1729-4061.2016.65671

Kononenko, I.V. \& Lutsenko, S.Yu. (2017). Method for selection of project management approach based on fuzzy concepts. Bulletin of NTU "KhPI". Series: Strategic management, portfolio, programand projectmanagement,2(1224), 
8-17. http://doi.org/10.20998/2413-3000.2017.1224.2

Kononenko, I.V. \& Lutsenko, S.Yu. (2018a). Evolution of the generalized body of knowledge on project management. Bulletin of NTU "KhPI". Series: Strategic Management, Portfolio, Program and Project Management, 2(1225), 17-22. https://doi.org/10.20998/124510

Kononenko, I. \& Lutsenko, S. (2018b). The Project Management Methodology and Guide Formation's Method. Proceedings of 2018 IEEE 13th International Scientific and Technical Conference on Computer Science and Information Technologies (CSIT) (pp. 156-159). Lviv, Ukraine. http://doi.org/10.1109/STC-CSIT.2018.8526621

Kryvinska, N. (2012). Building Consistent Formal Specification for the Service Enterprise Agility Foundation. Journal of Service Science Research, 4(2), 235-269. https://doi.org/10.1007/s12927-012-0010-5

PricewaterhouseCoopers (2012). Insights and Trends: Current Portfolio, Programme, and Project Management Practices The third global survey on the current state of project management. Retrieved from https:// www.pwc.com.tr/en/publications/arastirmalar/pages/pwc-global-project-management-report-small.pdf

Project Management Institute. (2017a). A Guide to the Project Management Body of Knowledge (PMBOK® Guide)-Sixth Edition. Newtown Square, PA: Project Management Institute.

Project Management Institute. (2017b). Agile Practice Guide. Newtown Square, PA: Project Management Institute.

Rehman, A., \& Hussain, R (2007). Software project management methodologies/frameworks dynamics "A comparative approach". Proceedings of International Conference on Information and Emerging Technologies (ICIET) (pp. 1-5). Karachi, Pakistan. SCRUMstudy (2016). A guide to the Scrum Body of Knowledge (SBOK Guide), 2016 Edition. SCRUMstudy, a brand of VMEdu, Inc., Phoenix, Arizona USA. 340 p. The Standish Group (2013). CHAOS Research Report 2013. Retrieved from https:/www.immagic.com/eLibrary/ARCHIVES/GENERAL/GENREF/S130301C.pdf Whitaker, S. (2014). The Benefits of Tailoring: Making a Project Management Methodology Fit. PMI White Paper
Igor Kononenko, received his Master's degree in radio electronics from Kharkiv Aviation Institute in 1973, his Ph.D. in technical cybernetics and information theory from Kharkiv Institute of Radio Electronics in 1979, and his DSc in Automation of technological processes and productions from Kharkiv State Polytechnic University in 1982. Since 2000, he has been Head of the Strategic Management Department of National Technical University "Kharkiv Polytechnic Institute". His areas of research include the modeling and optimization of complex systems, information technologies in strategic, portfolio, and project management. He is a professor, Laureate of the State Prize of Ukraine. He has been awarded the Order "For Merits" of the 3rd degree by the President of Ukraine (2015).

Svitlana Lutsenko, PhD student at National Technical University "Kharkiv Polytechnic Institute" (NTU "KhPI"), earned her Master of Computer Science and Information Technologies degree in 2018. Currently, she is working at the NTU "KhPI" Strategic Management Department as an assistant of the department. Her master thesis was on project management methodology selection; the aim of the research was to create a method that allows selecting the most suitable management methodology for a project. Her research interests include modeling, business analysis, fuzzy logic, and Agile project management. She has been awarded the prestigious scholarship of the President of Ukraine. 